\title{
Risk and Change Order Impact Analysis of Costs in Tamansari Iswara Bekasi Project
}

\author{
Ali Sunandar ${ }^{*} \&$ Kuncoro Bili Aszhari
}

Mercu Buana University, Bekasi, Indonesia

\begin{abstract}
In every construction project, there is always a change or what is commonly called a change order $(\mathrm{CO})$. $\mathrm{CO}$ greatly affects the effectiveness of project work where its sustainability depends on three interrelated components namely quality, time and cost. The purpose of this study is to determine the causes, risks, impact of CO and risk management on costs. This research was conducted in the Bekasi area at the Tamansari Iswara project. This study uses descriptive analysis methods and direct interviews with the experts concerned by distributing questionnaires to 85 respondents and producing data for analysis. With the help of statistical analysis software that is SPSS researchers use several tests such as validity test, reliability test, descriptive analysis test, regression analysis, and risk analysis to determine the dominant variables and risk management. From the results of the analysis conducted there are 6 dominant variables namely X18, X19, X15, X28, X21, X9, X25, and the highest risk is found in variables X1 and X21.
\end{abstract}

Keywords: Risk analysis; damp analysis; contract change order; contractor.

\section{Introduction}

Understanding the construction industry, in general, is all activities or businesses related to land preparation and construction processes, changes, improvements to buildings, structures, and other related facilities. While the definition of construction work according to Article 1 Paragraph 3 of Law no. 2 of 2017 concerning Construction Services is the whole or part of activities which include construction, operation, maintenance, demolition, and rebuilding of a building. Simply stated, there are 3 (three) important criteria that are the focus of construction projects, namely: cost, quality, and time. These three criteria will continue to be considered throughout the stages of the construction project cycle (Hansen, 2017). During the construction of change order construction can occur from the owner, the contractor, and also due to field conditions that do not allow it to proceed in the process of implementing the construction project. Change orders which include less added work, changing work schedule, and changing technical specifications of work that affect the performance of a construction project will have a direct or indirect negative impact on both the owner and the contractor himself, (Beatrix, et. al., 2013). The development of the Tamansari Iswara project uses a joint contract, namely: a Lump Sum Contract and a Unit Price Contract. However, in the implementation of the Tamansari Iswara project development many experienced obstacles in the field so that it affected the development implementation process. The existing constraints caused several changes to the employment contract. The number of issuance of addendum changes to the Bill of Quantity (BOQ) and the contract value by the service provider, is the cause for analyzing the main causes of changes in the contract of work (Contract Change order). As a result of frequent changes in orders (changes in work) where the administrative process is not carried out according to procedures, there are often disputes between the owner and the contractor that ends in arbitration (court). From this, it will be examined what are the main causes of change orders (job changes), and their impact on costs in the Tamansari Iswara project.

\footnotetext{
* Corresponding author.

E-mail address: ali.sunandar@gmail.com (Ali Sunandar)
} 
While the purpose of this research is:

a) Knowing the dominant variable causing contract change order

b) Knowing the risk management strategy in the Tamansari Iswara Bekasi project

\section{Literature Review}

\subsection{Understanding Order Changer}

Change Order is a written agreement to modify, add, or other changes to the work that has been set in the contract at the time of bid opening, provided that the change is still within the scope of the initial project (Khan, 2016). Change orders can include changes in contract prices, payment schedules, project completion schedules, or changes in drawings and specifications. Change orders can arise due to various reasons, some of which are: flawed or incomplete designs, changes in demand, unknown field conditions, unclear contract language, and acceleration orders (Osman, et.al., 2009).

\subsection{Purpose of Change Order}

According to Fisk \& Reinolds (2006) and Khan (2016), the objectives of the change order are:

- To change the contract plan with a special method of payment

- To change job specifications

- For the approval of additional new jobs

- For administrative purposes

- To follow the adjustment to the contract unit price

- For submission of cost reduction proposal incentives

- To adjust the project schedule due to change

- To avoid disputes between the contractor and the owner

\subsection{Factors That Cause Order Changer}

\begin{tabular}{ll}
\hline No & $\begin{array}{c}\text { The causal factors and the impact of the contract change order on cost performance in the } \\
\text { Tamansari Iswara project }\end{array}$ \\
\hline Planing and design factors \\
\hline X1 & $\begin{array}{l}\text { design blindness } \\
\text { design changes by consultant planners } \\
\text { X2 }\end{array}$ \\
X3 & Less detailed planner design \\
X4 & Completeness in contract documents \\
X5 & the mismatch between the picture and the state of the field \\
\hline Natural Conditions \\
\hline X6 & very bad weather \\
X7 & flooding \\
X8 & Land subsidence \\
\hline Owner Influence Factors \\
\hline X9 & Termination of work at the request of the owner \\
X10 & acceleration of work execution time due to the owner's request to quickly finish \\
X11 & delay in execution of work due to the owner's request \\
\hline X12 & a request for material change by the owner \\
X13 & changes in technical specifications of work items \\
\hline
\end{tabular}




\begin{tabular}{ll}
\hline No & $\begin{array}{c}\text { The causal factors and the impact of the contract change order on cost performance in the } \\
\text { Tamansari Iswara project }\end{array}$ \\
\hline X14 & being late in approving drawings (shop drawing) \\
\hline Contractor Influence Factors \\
\hline X15 & lack of control by the contractor in the implementation of construction \\
X16 & the discrepancy between contractor and subcontractor schedules \\
X17 & replacement of the foreman carried out by the contractor because the work did not match the contract \\
X18 & poor material control \\
X19 & lack of contractor teamwork in carrying out the work \\
X20 & lack of communication between field implementers and supervisory consultants \\
X21 & errors and omissions in calculating volume estimates \\
X22 & less quick decision making by the contractor \\
\hline Other Influencing Factors \\
\hline X23 & disputes between workers, be it consultants, contractors or owners \\
X24 & lack of management related to the security and scheduling of project personnel equipment materials \\
X25 & damage to equipment by irresponsible parties \\
X26 & land acquisition issues \\
X27 & material delivery by suppliers does not match the specifications \& schedule \\
X28 & inadequate equipment needs environmental \& social impacts due to adjacent residential areas \\
X29 & inadequate equipment needs environmental \& social impacts due to adjacent residential areas \\
\hline The Impact of a Terms of Cost \\
\hline X30 & Increased Overhead Costs \\
X31 & Increased equipment and material costs \\
\hline Impact of Time & Extension of time for work duration \\
\hline X32 & Added time for additional work, rework / redesign \\
X33 & Procurement of equipment and materials \\
X34 & A decrease in quality \\
\hline Impact in terms of quality \\
\hline X35 & there is a defect in the product \\
X36 & \\
X37 & \\
\hline
\end{tabular}

\subsection{Risk Management}

According to PMBOK Guide-Sixth Edition (2017), Risk Management is the process of defining how to carry out risk management activities for a project. The main benefit of this process is ensuring that the degree, type, and visibility of risk management are proportionate to the risks and importance of the project for the organization and other stakeholders. This process is carried out once or at a predetermined point in the project.

\section{Methods}

The method used in this research is data collection through a questionnaire distributed to several respondents. The analytical method used is descriptive quantitative. A quantitative approach is a research that focuses on testing hypotheses, the data used must be measurable, and produce conclusions that can be generalized. This approach uses inferential statistical (analytical tool) methods.

The flowchart of the study in this study is as follows in fig. 1. 


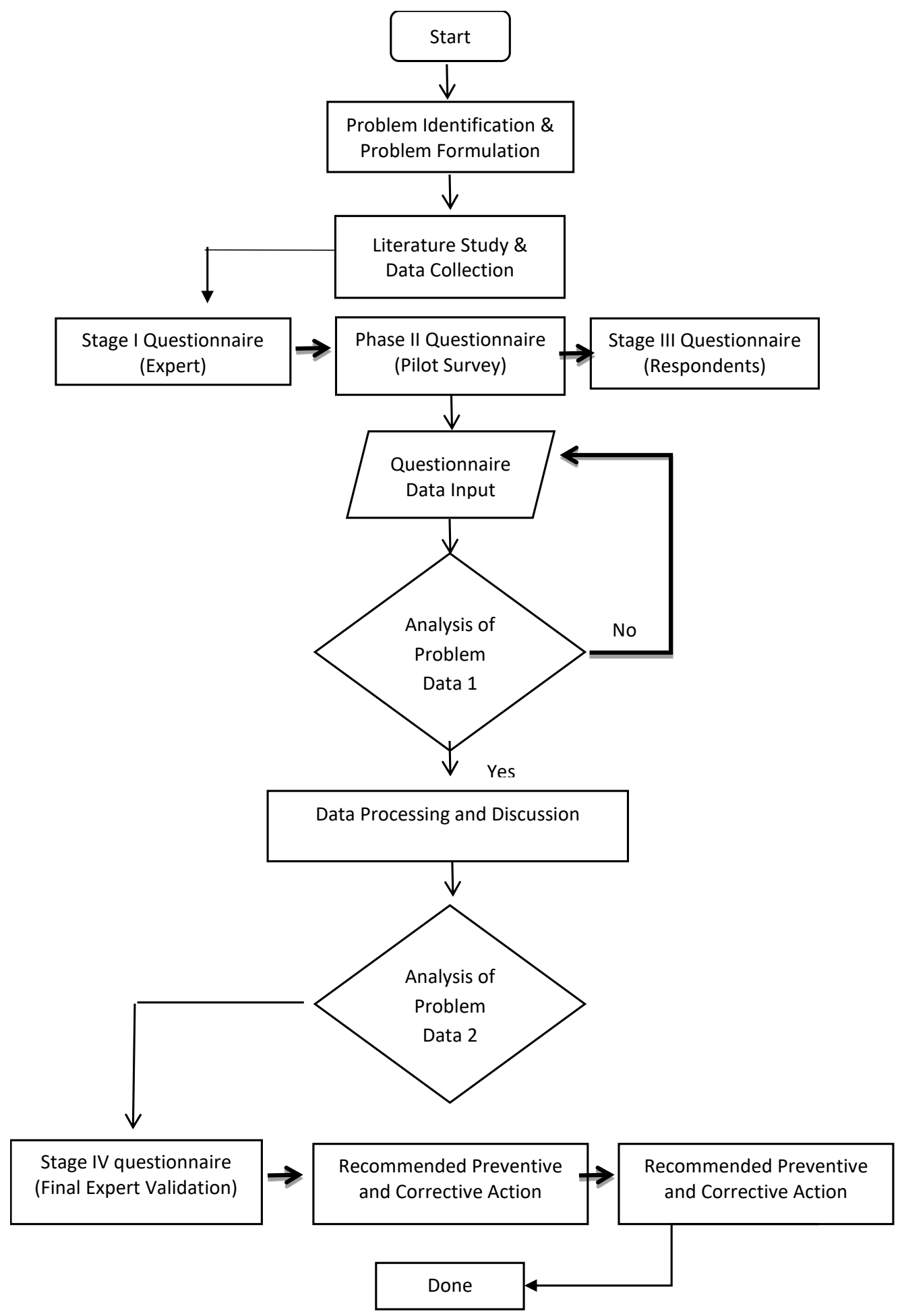

Fig. 1. Flowchart of Study 


\section{Result and Discussions}

Data collection consisted of four stages which began with the distribution of questionnaires to 3 experts, followed by the distribution of pilot survey questionnaires, then the distribution of questionnaires to respondents and finally the validation of the final stage of experts to find out risk management. From 37 variables validated by experts, filtered to 31 variables to be analyzed. The filtered variables are X4, X5, X7, X8, X20, and X37.

\subsection{Validity and Reliability Results}

For reliability testing, Cronbach's alpha method is used where the value must be greater than 0.6 for each variable and 0.8 for the entire variable to be considered reliable. Based on the reliability test results obtained show that all items of the variables in the study can be declared reliable and have a high level of reliability.

Table 1. Result of reliability test

\begin{tabular}{cc}
\hline Cronbach's Alpha & N of Items \\
\hline 0.864 & 31 \\
\hline
\end{tabular}

\subsection{Spearman Rank Correlation Results}

The Spearman Rank Test is used to see whether the relationship is significant or not, by referring to the column correlation coefficient ( $r$ count) compared to the $r$ table value. The table value is 0.213 . for statistical decision making is a variable that has a correlation coefficient $>0.213$.

Table 2. Result of Spearman Rank Test

\begin{tabular}{cccc}
\hline Variabel & $\mathrm{N}$ & Correlation Coefficient & Sig. (2-tailed) \\
\hline X6 & 85 & 0.211 & 0.052 \\
X9 & 85 & $0.559^{* *}$ & 0.000 \\
X10 & 85 & $0.459^{* *}$ & 0.000 \\
X11 & 85 & $0.437^{* *}$ & 0.000 \\
X12 & 85 & 0.062 & 0.574 \\
X13 & 85 & $0.451^{* *}$ & 0.000 \\
X15 & 85 & $0.371^{* *}$ & 0.000 \\
X16 & 85 & $0.408^{* *}$ & 0.000 \\
X17 & 85 & $0.494^{* *}$ & 0.000 \\
X18 & 85 & $0.608^{* *}$ & 0.000 \\
X19 & 85 & $0.580^{* *}$ & 0.000 \\
X21 & 85 & $0.589^{* *}$ & 0.000 \\
X22 & 85 & $0.436^{* *}$ & 0.000 \\
X23 & 85 & $0.273^{*}$ & 0.011 \\
X24 & 85 & $0.367^{* *}$ & 0.001 \\
X25 & 85 & $0.452^{* *}$ & 0.000 \\
X26 & 85 & $0.328^{* *}$ & 0.002 \\
\hline
\end{tabular}




\begin{tabular}{cccc}
\hline Variabel & $\mathrm{N}$ & Correlation Coefficient & Sig. (2-tailed) \\
\hline X27 & 85 & $0.490^{* *}$ & 0.000 \\
X28 & 85 & $0.490^{* *}$ & 0.000 \\
X29 & 85 & $0.458^{* *}$ & 0.000 \\
X30 & 85 & $0.220^{*}$ & 0.043 \\
X31 & 85 & $0.241^{*}$ & 0.026 \\
X32 & 85 & $0.376^{* *}$ & 0.000 \\
X33 & 85 & $0.235^{*}$ & 0.031 \\
X34 & 85 & $0.385^{* *}$ & 0.000 \\
X35 & 85 & $0.344^{* *}$ & 0.001 \\
X36 & 85 & $0.215^{*}$ & 0.048 \\
\hline
\end{tabular}

From the above table, it can be concluded that the variables that are stated to have significant correlation levels are X9, X10, X11, X13, X15, X16, X17, X18, X19, X21, X22, X23, X24, X25, X26, X27, X28, X29, X30, X31, X32, $\mathrm{X} 33, \mathrm{X} 34, \mathrm{X} 25$ and $\mathrm{X} 36$.

\subsection{Regression Analysis Results}

The relationship model between pineapple variables (CCO factors) to the dependent variable (Cost Performance) was studied by regression analysis using the help of a statistical processing program. The input for this regression analysis is the dominant variable in determining the factors that cause change order. The outputs of the regression analysis can be seen in Table 3.

Table 3. Model Summary of Regression Analysis

\begin{tabular}{ccccc}
\hline Model & $\mathrm{R}$ & R Square & Adjusted R Square & Std. Error of the Estimate \\
\hline 1 & $.620^{\mathrm{a}}$ & 0.384 & 0.377 & 0.440 \\
2 & $.743^{\mathrm{b}}$ & 0.551 & 0.540 & 0.378 \\
3 & $.804^{\mathrm{c}}$ & 0.646 & 0.633 & 0.337 \\
4 & $.841^{\mathrm{d}}$ & 0.707 & 0.692 & 0.309 \\
5 & $.871^{\mathrm{e}}$ & 0.759 & 0.744 & 0.282 \\
6 & $.881^{\mathrm{f}}$ & 0.776 & 0.759 & 0.274 \\
7 & $.889^{\mathrm{g}}$ & 0.790 & 0.771 & 0.267 \\
\hline
\end{tabular}

a. Predictors: (Constant), X18

b. Predictors: (Constant), X18, X19

c. Predictors: (Constant), X18, X19, X15

d. Predictors: (Constant), X18, X19, X15, X28

e. Predictors: (Constant), X18, X19, X15, X28, X21

f. Predictors: (Constant), X18, X19, X15, X28, X21, X9

g. Predictors: (Constant), X18, X19, X15, X28, X21, X9, X25 
The model which has the highest $\mathrm{R}$ square value is model 7. The correlation/relationship value (R) is equal to .889 and the magnitude of the influence of the independent variable on the dependent variable is called the coefficient of determination (R2) of .790, meaning the effect of the variable free to the dependent variable is $79 \%$, while the rest is influenced by other variables.

Table 4. Coefficients of $\mathrm{T}$ test

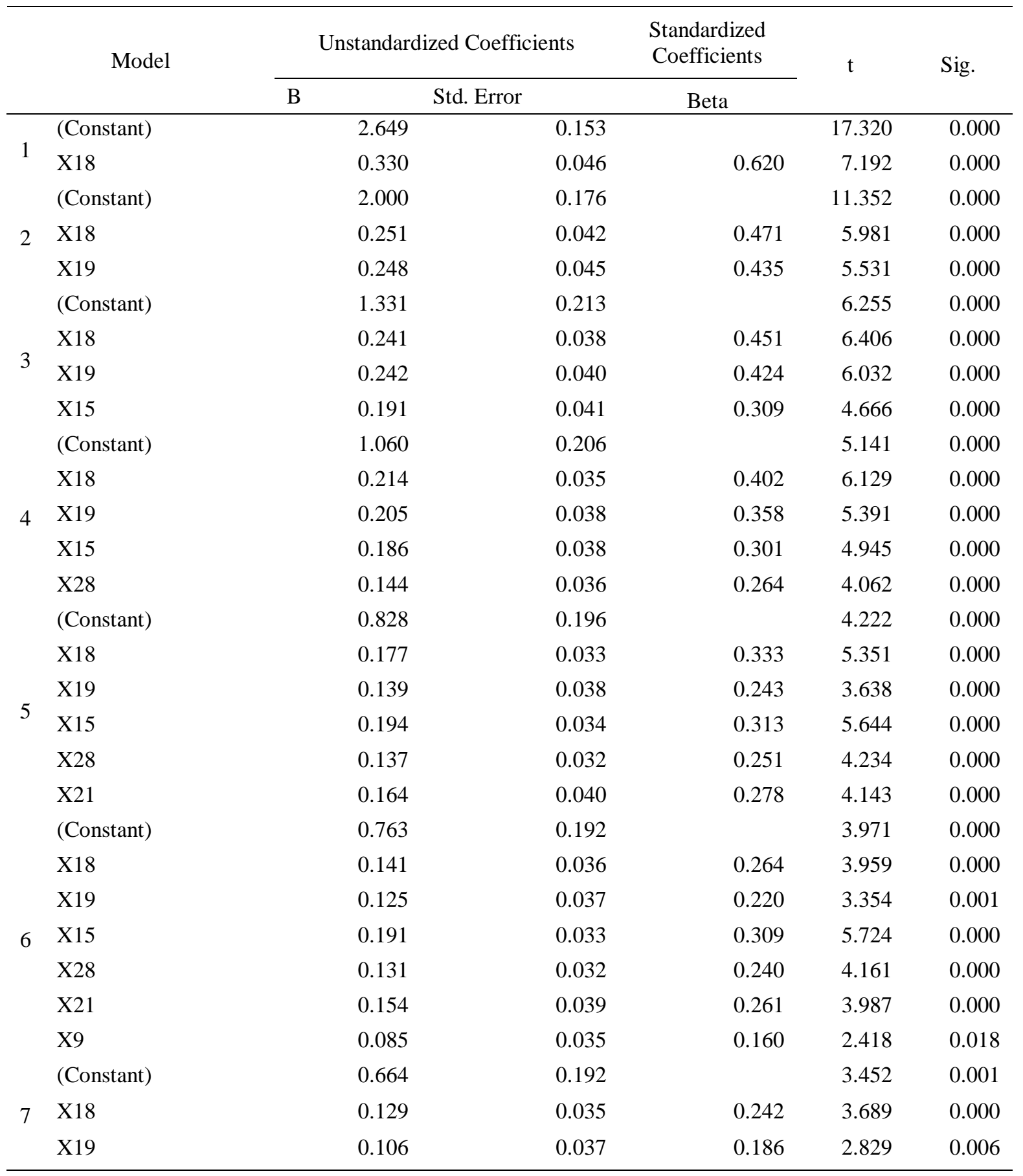




\begin{tabular}{|c|c|c|c|c|c|}
\hline \multirow{2}{*}{ Model } & \multicolumn{2}{|c|}{ Unstandardized Coefficients } & \multirow{2}{*}{$\begin{array}{c}\text { Standardized } \\
\text { Coefficients } \\
\text { Beta }\end{array}$} & \multirow{2}{*}{$\mathrm{t}$} & \multirow{2}{*}{ Sig. } \\
\hline & B & Std. Error & & & \\
\hline $\mathrm{X} 15$ & 0.194 & 0.033 & 0.314 & 5.968 & 0.000 \\
\hline $\mathrm{X} 28$ & 0.112 & 0.032 & 0.206 & 3.524 & 0.001 \\
\hline $\mathrm{X} 21$ & 0.152 & 0.038 & 0.259 & 4.045 & 0.000 \\
\hline X9 & 0.084 & 0.034 & 0.160 & 2.478 & 0.015 \\
\hline $\mathrm{X} 25$ & 0.077 & 0.034 & 0.136 & 2.261 & 0.027 \\
\hline
\end{tabular}

So, the equation can be written as follows:

$$
\mathrm{Y}=0.664+0.129 \mathrm{X} 18+0.106 \mathrm{X} 19+0.194 \mathrm{X} 15+0.112 \mathrm{X} 28+0.152 \mathrm{X} 21+0.084 \mathrm{X} 9+0.077 \mathrm{X} 25
$$

Description:

$\mathrm{Y}=$ Cost Performance

$\mathrm{X} 18$ = Inadequate Material Control Variable

X19 = Contractor Team Work Variable in Work Implementation

$\mathrm{X} 15$ = Variable Lack of Control By the Contractor in the Implementation of Construction

$\mathrm{X} 28$ = Inadequate Equipment Requirement Variable

$\mathrm{X} 21=$ Variable Errors and Omissions in Volume Estimation Calculations

$\mathrm{X} 9=$ Job Termination Variable at Owner Request

X25 = Variable Occurrence of Equipment Damage by Irresponsible Parties

Hypothesis: from the results of the output of table 4, we can know the significance value of $0.000<0.05$, then $\mathrm{H} 0$ is rejected and H1 is accepted. Statement H0 is that if there is no risk and CCO impact analysis on cost performance, then the project cost performance management will not be controlled. Whereas H1 statement is: If an analysis of risk identification and the impact of CCO on cost performance is carried out, then project cost management will be controlled, which means there is a significant (significant) influence on variables (X18, X19, X15, X28, X21, X9, and $\mathrm{X} 25)$ on variable $\mathrm{Y}$.

\subsection{Analys Risk}

The variables of the results of the data collection of respondents who have been reduced from the results of the validity and reliability tests are input from this stage of the analysis, namely many 31 variables. Risk ranking analysis is performed on the results of calculation of the average value of frequency and impact of risk.

The range for determining risk is as follows:

- Low risk: $0.01-0.05$

- Moderate risk: $0.06-0.25$

- High risk: $0.25-0.72$

The following risk values and risk categories are shown in the table 5 . 
Sunandar, et.al | Quantitative Economics and Management Studies (QEMS), 2021, 2(4): 261-271

Table 5. Value Table and Risk Category

\begin{tabular}{|c|c|c|c|c|}
\hline Variabel & Impact (D) & Frekuensi (F) & Risk (D X F) & Category Risk \\
\hline $\mathrm{X} 1$ & 0.52 & 56.1 & 29.11 & High \\
\hline $\mathrm{X} 2$ & 0.44 & 51.5 & 22.84 & Medium \\
\hline $\mathrm{X} 3$ & 0.38 & 54.9 & 21.12 & Medium \\
\hline $\mathrm{X} 6$ & 0.35 & 45.5 & 16.14 & Medium \\
\hline $\mathrm{X} 9$ & 0.36 & 46.7 & 16.98 & Medium \\
\hline $\mathrm{X} 10$ & 0.43 & 51.9 & 22.10 & Medium \\
\hline $\mathrm{X} 11$ & 0.40 & 55.5 & 22.46 & Medium \\
\hline $\mathrm{X} 12$ & 0.38 & 49.5 & 19.04 & Medium \\
\hline $\mathrm{X} 13$ & 0.42 & 52.7 & 22.01 & Medium \\
\hline X14 & 0.36 & 49.5 & 17.94 & Medium \\
\hline $\mathrm{X} 15$ & 0.38 & 51.7 & 19.40 & Medium \\
\hline $\mathrm{X} 16$ & 0.29 & 38.5 & 11.23 & Medium \\
\hline $\mathrm{X} 17$ & 0.38 & 47.9 & 18.26 & Medium \\
\hline $\mathrm{X} 18$ & 0.36 & 50.7 & 18.43 & Medium \\
\hline X19 & 0.36 & 46.7 & 16.81 & Medium \\
\hline $\mathrm{X} 21$ & 0.47 & 56.7 & 26.75 & High \\
\hline $\mathrm{X} 22$ & 0.35 & 47.9 & 16.57 & Medium \\
\hline $\mathrm{X} 23$ & 0.34 & 43.7 & 14.91 & Medium \\
\hline $\mathrm{X} 24$ & 0.31 & 50.3 & 15.74 & Medium \\
\hline $\mathrm{X} 25$ & 0.34 & 49.7 & 16.87 & Medium \\
\hline $\mathrm{X} 26$ & 0.37 & 42.7 & 15.62 & Medium \\
\hline $\mathrm{X} 27$ & 0.38 & 51.1 & 19.24 & Medium \\
\hline $\mathrm{X} 28$ & 0.44 & 48.3 & 21.31 & Medium \\
\hline X29 & 0.36 & 43.3 & 15.69 & Medium \\
\hline $\mathrm{X} 30$ & 0.34 & 50.7 & 17.42 & Medium \\
\hline $\mathrm{X} 31$ & 0.41 & 56.9 & 23.36 & Medium \\
\hline $\mathrm{X} 32$ & 0.38 & 51.1 & 19.36 & Medium \\
\hline $\mathrm{X} 33$ & 0.37 & 50.1 & 18.39 & Medium \\
\hline X34 & 0.39 & 49.9 & 19.43 & Medium \\
\hline $\mathrm{X} 35$ & 0.40 & 52.7 & 21.27 & Medium \\
\hline $\mathrm{X} 36$ & 0.33 & 47.3 & 15.61 & Medium \\
\hline
\end{tabular}

Source: Researcher's Processed Data, 2020

The highest risk from the table of values and risk categories can be seen as follows:

$\mathrm{X} 1$ : Design invasion

$\mathrm{X} 21$ : errors and omissions in calculating volume estimates 


\section{Conclusions}

Based on the analysis and discussion that has been presented in the previous chapter, it can be concluded that several dominant variables cause the contract change order in the Tamansari Iswara Apartment project, namely:

\begin{tabular}{cl}
\hline Variable & The causative factor of CCO \\
\hline X9 & Termination of work at the request of the owner \\
X15 & lack of control by the contractor in the implementation of construction \\
X18 & poor material control \\
X19 & lack of contractor teamwork in carrying out the work \\
X21 & errors and omissions in calculating volume estimates \\
X25 & damage to equipment by irresponsible parties \\
X28 & inadequate equipment needs \\
\hline
\end{tabular}

After obtaining the risks that have a high correlation with cost performance, a strategy or solution can be made to overcome these risks which are explained below:

\begin{tabular}{ccl}
\hline Variable & Statement & \multicolumn{1}{c}{ Solution } \\
\hline X1 & Agree & $\begin{array}{l}\text { Compile a picture that is not appropriate/problematic and immediately inform } \\
\text { the owner and construction management so that it is immediately forwarded to } \\
\text { the consultant to immediately be repaired }\end{array}$ \\
& $\begin{array}{l}\text { Submitting changes in design/items / job specifications so that there is no } \\
\text { significant change in costs from the initial contract }\end{array}$ \\
X21 & Agree & $\begin{array}{l}\text { File VO changes in accordance with errors with adjusted unit prices } \\
\text { nat }\end{array}$
\end{tabular}

Recommendations:

a. This study specifically reviews the risks and impacts of contract change orders on the cost performance of the Tamansari Isawara Apartment project. Future studies can identify at the control stage.

b. This research specifically reviews the risk and impact of the contract change order on the Tamansari Iswara Apartment project which is seen from the perspective of the service user, so that it can then be examined from the perspective of the service provider.

\section{References}

Beatrix, M., \& Wiguna, I. P. A. (2013). Analisa Pengaruh Change Order Terhadap Biaya, Waktu dan Mutu Proyek Konstruksi di Surabaya. Prosiding Seminar Nasional Manajemen Teknologi XX. 1-7.

Fisk, E.R. \& Reynolds, W. D. (2006). Construction project administration. New Jersey: Prentice Hall. 
Hansen, S. (2017). Quantity Surveying: Pengantar Manajemen Biaya dan Kontrak Konstruksi. Gramedia Pustaka Utama.

Khan, O. H. (2016). Effective framework for change order management in construction industry. Professional Masters project, Qatar university.

Osman, Z., Omran, A., \& Foo, C. K. (2009). The potential effects of variation orders in construction projects, Journal of Engineering, 7, 141-152.

PMBOK Guide-Sixth Edition. (2017). Project Management Institution. Retrieved from: https://www.pmi.org/pmbokguide-standards/foundational/pmbok 